\title{
Changes in exhaled carbon monoxide and nitric oxide levels following allergen challenge in patients with asthma
}

\author{
P. Paredi ${ }^{*}$, M.J. Leckie*, I. Horvath*, L. Allegra ${ }^{+}$, S.A. Kharitonov*, P.J. Barnes*
}

Changes in exhaled carbon monoxide and nitric oxide levels following allergen challenge in patients with asthma. P. Paredi, M.J. Leckie, I. Horvath, L. Allegra, S.A. Kharitonov, P.J. Barnes. (C)ERS Journals Ltd 1999.

ABSTRACT: Carbon monoxide is a product of haem degradation by haem oxygenase (HO), activated by inflammatory cytokines and oxidants. This study examined whether allergen challenge can increase exhaled $\mathrm{CO}$ levels, as a reflection of $\mathrm{HO}$ activation.

Exhaled CO and nitric oxide, an expired gas also thought to reflect cytokine-induced airway inflammation, were measured in 15 atopic steroid-naive nonsmoking patients with asthma (13 males, aged $30 \pm 2$ yrs) before and for up to $20 \mathrm{~h}$ after allergen challenge.

Baseline CO (4.4 \pm 0.3 parts per million ( $\mathrm{ppm})$ ) and NO (20.6 \pm 1.2 parts per billion (ppb)) levels were elevated in asthmatic as compared with nonsmoking normal volunteers $(\mathrm{n}=37,2.1 \pm 0.2 \mathrm{ppm}$ and $7.0 \pm 0.1 \mathrm{ppb}$, respectively, $\mathrm{p}<0.05)$. In 10 patients with a dual response in the forced expiratory volume in one second (FEV1) there was a maximal increase in exhaled $\mathrm{CO}$ at $1 \mathrm{~h}(34.3 \pm 7.1 \%)$ and at $6 \mathrm{~h}(69 \pm 12 \%, \mathrm{p}<0.01)$, followed by a maximal fall in FEV $1(28 \pm 9 \%, p<0.05)$ at $9 \mathrm{~h}$, whereas the maximal NO increase was observed at $10 \mathrm{~h}(50.2 \pm 11.8 \%)$. The maximal increase in exhaled $\mathrm{CO}$ in single response patients $(n=5)$ was $30 \pm 2 \%$ during the early asthmatic reaction and $46.3 \pm$ $9.2 \%$ between 4 and $10 \mathrm{~h}$, followed by a fall in FEV1 $(9 \pm 3 \%, p>0.05)$ at $9 \mathrm{~h}$, whereas exhaled NO was not significantly changed. In five patients exhaled $\mathrm{CO}$ was not attenuated by inhalation of increasing concentrations of histamine causing a $20 \%$ fall in FEV1 (PC20) or its subsequent relief by $\beta_{2}$-agonists.

In conclusion, exhaled carbon monoxide is increased during the early and late asthmatic reactions independently of the change in airway calibre, while exhaled nitric oxide is increased only during the late reaction and follows the increase in carbon monoxide and fall in the forced expiratory volume in one second in time. Eur Respir J 1999; 13: 48-52.
*Dept of Thoracic Medicine, Imperial College School of Medicine at the National Heart and Lung Institute, London, UK. 'Institute of Lung Disease, IRCCS, Polyclinic Hospital University of Milan, Italy.

\section{Correspondence: P.J. Barnes}

Dept of Thoracic Medicine

National Heart and Lung Institute

Dovehouse Street

London SW3 6LY

UK

Fax: 441713518126

Keywords: Allergen challenge

asthma

carbon monoxide

inflammation

nitric oxide

oxidative stress

\section{Received: February 261998}

Accepted after revision August 181998

Supported by grants from the University of Milan School of Respiratory Disease and the British Lung Foundation (UK).
There is considerable evidence for airway inflammation and oxidative stress in patients with asthma, even when the disease is mild $[1,2]$. Bronchoalveolar lavage (BAL) and bronchial biopsy studies have demonstrated the infiltration of activated inflammatory cells in the airway mucosa and there is a broad relationship between the intensity of inflammation and the clinical severity of asthma. Inhalation of allergen provides a model of asthmatic inflammation, as it provokes an early fall in forced expiratory volume in one second (FEV1) owing to the release of bronchoconstrictor mediators, such as histamine, leukotrienes and prostaglandins [3], and a late asthmatic response which is associated with a prolonged bronchoconstriction, influx of inflammatory cells [4] and mediators [5-7] and an increase in the oxidative stress in the airway.

It is becoming clear that some oxidant-induced mediators and enzymes, such as haem oxygenase (HO), may also play a vital role in the airway protective response to oxidative stress. Two isoforms of $\mathrm{HO}$ have been described: the constitutive HO-2, which is highly expressed in the brain and testes, and the inducible HO-1, which is ubiquitously distributed. The latter is activated by a variety of pro-inflammatory cytokines [8, 9], nitric oxide [10, 11], hydrogen peroxide, endotoxin [12], and oxidants [13] and is an important part of a protective response to oxidative stress $[14,15]$.

Carbon monoxide is a product of haem degradation by $\mathrm{HO}$ and is recognized as an important signalling molecule $[16,17]$. Recently, elevated levels of CO have been found in the exhaled air of asthmatic patients and may reflect the degree of HO-1 induction [18, 19].

$\mathrm{NO}$ is a gas produced by several types of pulmonary cells, including inflammatory, endothelial and airway epithelial cells [20]. Elevated levels of exhaled NO in asthma $[21,22]$ and bronchiectasis [23] are likely to be due to the activation of the inducible form of NO synthase (iNOS) [24], and therefore, reflect airway inflammation. A six-fold increase in iNOS expression [7] and elevated levels of exhaled NO $[25,26]$ have been shown following allergen challenge, confirming the possible role of $\mathrm{NO}$ as a noninvasive marker of inflammation.

It was hypothesized that elevated levels of exhaled $\mathrm{CO}$ in patients with asthma would be further increased after allergen challenge, as a reflection of HO-1 induction by 
inflammatory cytokines and oxidative stress; therefore, exhaled CO levels were measured and compared with the levels of exhaled NO.

\section{Subjects and methods}

\section{Patients}

Eighteen asthmatic subjects aged $27 \pm 2$ yrs had a positive cutaneous response (skin-prick test $>3 \mathrm{~mm}$ weal) to common aeroallergens (cat dander, house dust mites, grass pollen). All had FEV1 values $>80 \%$ of predicted normal and provocative concentration of histamine causing a $20 \%$ fall in FEV1 (PC20) values of $>0.03 \mathrm{mg} \cdot \mathrm{mL}^{-1}$ and did not require corticosteroid treatment in the 3 months before the study. None of the 37 nonsmoking controls ( 20 males, aged $33 \pm 2.8$ yrs) had a history of respiratory or cardiovascular disease or was receiving long-term medication. There was no history of upper respiratory tract infection for at least 4 weeks before the study in any of the studied patients.

Subjects did not consume any caffeine for $2 \mathrm{~h}$ or inhaled $\beta_{2}$-agonists for $8 \mathrm{~h}$ before challenge. The smoking status of all the subjects was confirmed by nicCheck I (DynaGen, Cambridge, MA, USA), which detects nicotine and its metabolites in the urine. Active and passive smokers (smoke exposure for $>30 \mathrm{~min}^{\mathrm{day}}{ }^{-1}$ ) were excluded from the study. All patients had at least $1 \mathrm{~h}$ rest before allergen challenge, in order to eliminate the effect of any possible exposure to high $\mathrm{CO}$ concentrations during their journey to the hospital.

\section{Allergen challenge}

The subjects were challenged with the allergen that caused the largest weal on skin-prick tests. Allergen inhalation tests were performed using a nebulizer (Dosimeter MB3; MEFAR Electromedical, Bovezzo, Italy) with an output of $200 \mu \mathrm{L}$. Freeze-dried allergen extracts (Aquagen SQ; Allerayde, Nottingham, UK) were diluted to give final concentrations of $200,1,000,2,500,5,000,12,500,25,000$ and $50,000 \mathrm{IU} \cdot \mathrm{mL}^{-1}$. The initial dose for the allergen inhalation test was $200 \mathrm{IU} \cdot \mathrm{mL}^{-1}$, and FEV1 was measured 5 and 10 min after each dose. FEV1 was measured using a dry wedge spirometer (Vitalograph, Buckingham, UK). Serially increasing doses of allergen were inhaled and the cumulative dosage resulting in a $15 \%$ reduction in FEV1 at 10 min was recorded. FEV1 was measured at 5, 10, 20, 30, 45 and $60 \mathrm{~min}$, then at 30 -min intervals until $3 \mathrm{~h}$, then at 4 , $5,6,7,8,9,10$ and $20 \mathrm{~h}$. An early asthmatic response was defined as a $>15 \%$ fall in FEV1 (postsaline FEV1) at 10 min after antigen challenge and a late asthmatic response as a $>15 \%$ fall in FEV1 from baseline on three occasions (postsaline FEV1) 4-10 h after challenge.

\section{Histamine challenge}

Histamine challenge was performed with doubling concentrations of histamine in the range $0.06-32 \mathrm{mg} \cdot \mathrm{mL}^{-1}$. After an initial $0.9 \%$ saline inhalation, patients were ex- posed to doubling concentrations of histamine delivered as five breaths from a dosimeter (Dosimeter MB3) at 3-min intervals until FEV1 fell by $>20 \%$ from the postsaline value. FEV1 was measured 2 min after each inhalation and salbutamol relief was administered when PC20 was reached.

\section{Exhaled carbon monoxide}

Exhaled $\mathrm{CO}$ was measured by a modified analyser (EC50-MICRO Smokerlyzer CO monitor; Bedfont Scientific, Kent, UK) sensitive to CO from 1-500 parts per million (ppm), adapted for online recording of $\mathrm{CO}$ concentration. The subjects exhaled slowly from total lung capacity (TLC) over 20-30 s with a constant flow (5-6 $\mathrm{L} \cdot \mathrm{min}^{-1}$ ) into the analyser to standardize exhalation flow rate and minimize the effect of flow dependency on the final exhaled $\mathrm{CO}$ levels [27], and against a resistance generating a mouth pressure of $0.4 \pm 0.05 \mathrm{kPa}(3 \pm 0.4 \mathrm{mmHg})$ shown previously to close the soft palate, thus eliminating ambient and nasal contamination of exhaled air [28]. Two successive recordings were made and the maximum values were used in all calculations. Ambient $\mathrm{CO}$ levels were recorded before each measurement.

\section{Exhaled nitric oxide}

Exhaled NO was measured using a modified chemiluminescence analyser (model LR2000; Logan Research, Rochester, UK), sensitive to NO from $1-5,000$ parts per billion (ppb) and with a resolution of $0.3 \mathrm{ppb}$, which was designed for online recording of exhaled NO concentrations, as described previously [29]. The analyser was calibrated using certified NO mixtures ( $90 \mathrm{ppb}$ and $436 \mathrm{ppb})$ in nitrogen (BOC Special Gases, Guildford, UK). Measurements of exhaled NO were made by slow exhalation $\left(5-6 \mathrm{~L} \cdot \mathrm{min}^{-1}\right)$ from TLC for $20-30 \mathrm{~s}$ against resistance $(0.04 \pm 0.05 \mathrm{kPa}(3 \pm 0.4 \mathrm{mmHg}))$.

\section{Experimental protocol}

Fifteen asthmatic patients were admitted to the Clinical Studies Unit (CSU), Royal Brompton Hospital, for an allergen challenge. Exhaled $\mathrm{CO}$ and $\mathrm{NO}$ were measured at baseline, at 5, 10, 20, 30, 45 and $60 \mathrm{~min}$, then at 30-min intervals until $3 \mathrm{~h}$, then at 4, 5, 6, 7, 8, 9, 10 and $20 \mathrm{~h}$. Cardiac frequency, blood pressure and FEV1 were monitored until they returned to baseline values. In addition, two of the patients who were submitted to the allergen challenge and three other asthmatic patients underwent histamine challenge. Exhaled $\mathrm{CO}$ was measured at baseline, every $2 \mathrm{~min}$ after inhalation and every $30 \mathrm{~min}$ for up to $2 \mathrm{~h}$ after salbutamol administration. FEV1 was monitored every 2 min until a return of baseline FEV1.

\section{Statistics}

All results were expressed as means \pm SEM. Comparisons between groups were made by two-way analysis of variance (ANOVA) with Bonferroni's correction for multiple 
comparisons. The relationships between exhaled $\mathrm{CO}$, NO and change in FEV1 were tested with the linear correlation coefficient. The cumulative effect of allergen challenge on exhaled $\mathrm{CO}$ and $\mathrm{NO}$ was expressed as the area under the curve (AUC). A p-value $<0.05$ was considered significant.

\section{Results}

Ten asthmatic patients had both an early and a late asthmatic response (dual responders) and five had an isolated early response (single responders).

Baseline exhaled CO levels were equally elevated in dual responders $(4.9 \pm 0.3 \mathrm{ppm})$, single responders $(4.7 \pm 0.3$ ppm) and asthmatic subjects who underwent histamine challenge $(4.2 \pm 0.2 \mathrm{ppm})$ compared with a control group of 37 nonsmoking subjects $(2.1 \pm 0.2 \mathrm{ppm}, \mathrm{p}<0.05)$.

Exhaled CO levels were elevated during both the early (maximum change from baseline $34 \pm 7 \%$ at $60 \mathrm{~min}$, AUC $11 \pm 1 \mathrm{au}$; fig. 1a) and late asthmatic reaction in dual responders (maximum change from baseline $69 \pm 12 \%$ at $6 \mathrm{~h}$, AUC $29 \pm 1 \mathrm{au}$ ). The maximum fall in FEV1 was $23 \pm 3 \%$ at $10 \mathrm{~min}$ and $28 \pm 9 \%$ at $9 \mathrm{~h}$ after allergen challenge.

Exhaled $\mathrm{CO}$ was also elevated in single responders during the early asthmatic reaction (maximum change from baseline $30 \pm 2 \%$ at $60 \mathrm{~min}$; AUC $3 \pm 1 \mathrm{au}$; fig. 1b) and
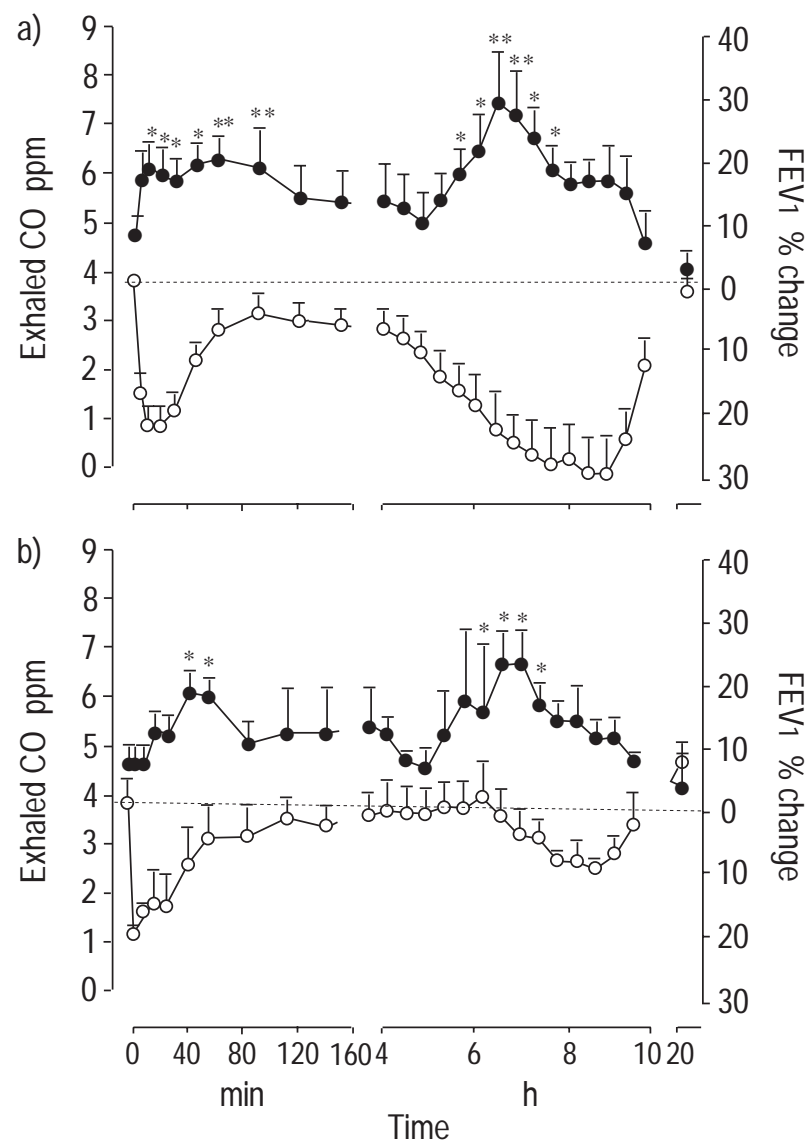

Fig. 1. - Change in exhaled carbon monoxide (๑) and forced expiratory volume in one second (FEV1; $O$ ) after allergen challenge in a) 10 patients who showed a dual response and $b$ ) five patients with a single response. Mean values \pm SEM are shown. ppm: parts per million. *: $\mathrm{p}<0.05$; **: $\mathrm{p}<0.01$. between 4 and $10 \mathrm{~h}$ after allergen inhalation (AUC 20 \pm 1 $\mathrm{au}, \mathrm{p}<0.05)$. The increase in exhaled $\mathrm{CO}$ was lower in single responders than in dual responders both during the early and late asthmatic reaction.

Exhaled $\mathrm{CO}$ returned to baseline by $20 \mathrm{~h}$ in both dual and single responders. There was no correlation between the magnitude of the $\mathrm{CO}$ response and FEV1 change in either group.

Baseline exhaled NO levels were comparable in dual $(20.6 \pm 1.5 \mathrm{ppb})$ and single responders $(20.6 \pm 1.8 \mathrm{ppb})$.

In patients who had a dual response there was a significant increase in exhaled NO during the late reaction (mean maximum increase $50.2 \pm 11.8 \% 10 \mathrm{~h}$ after challenge; fig. 2a).

In single responders there was no significant change in exhaled NO at any of the time points studied (fig. 2b).

\section{Histamine challenge}

In five patients histamine challenge produced a concentration-dependent reduction in FEV1 with maximum fall of $28 \pm 7 \%$, but with no change in $\mathrm{CO}$ (maximum $\mathrm{CO}$ fall $4 \pm 1 \%, \mathrm{p}>0.05$ ) and without subsequent changes at 30,60 , 90 or 120 min following salbutamol administration (data not shown).
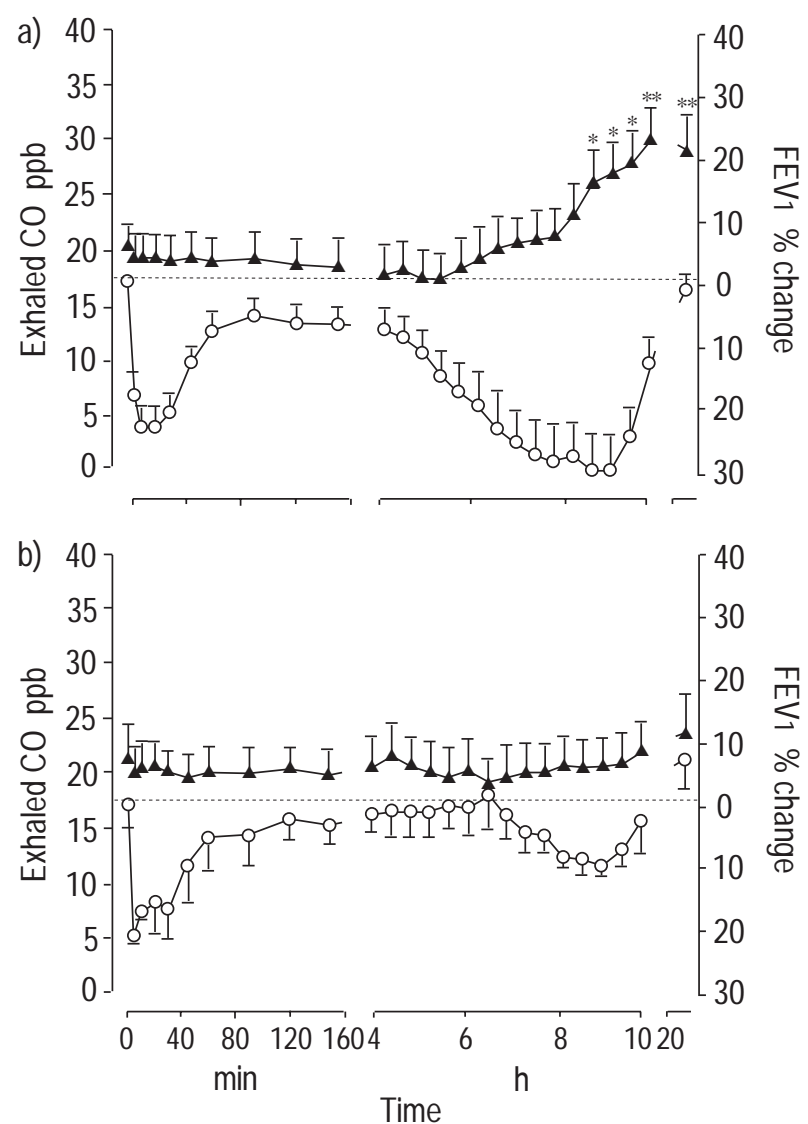

Fig. 2. - Change in exhaled nitric oxide ( $\boldsymbol{\Delta})$ and forced expiratory volume in one second (FEV1; $\bigcirc$ ) after allergen challenge in a) 10 patients who showed a dual response and $b$ ) five patients with a single response. Mean values \pm SEM are shown. ppb: parts per billion. *: $\mathrm{p}<0.05 ; * *: \mathrm{p}<$ 0.01 


\section{Discussion}

The results show that exhaled $\mathrm{CO}$ levels are increased during both the late and early asthmatic reaction independently of acute changes in airway calibre, but precede the fall in FEV1 during the late asthmatic reaction in dual responders. Exhaled NO levels were elevated in dual responders after the late fall in FEV1, whereas single responders showed no significant increase in exhaled NO.

The activation of HO-1 by prostaglandins [30] released by mast cells during the early asthmatic reaction $[3,31]$ may explain the elevated levels of exhaled $\mathrm{CO}$ during this phase. The absence of significant changes in exhaled NO levels is possibly due to the inability of prostaglandins and other compounds released during the early reaction, such as leukotrienes and histamine, to activate iNOS.

Much higher levels of exhaled CO and NO during the late asthmatic reaction may also be due to $\mathrm{HO}-1$ activation by inflammatory cytokines such as interleukin (IL)-1, IL-6, tumour necrosis factor (TNF- $\alpha)[32,33]$ and iNOS activation by IL- 1 and TNF- $\alpha[34,35]$ which are abundant in BAL at the time of the late asthmatic reaction [36, 37]. Increased production of oxidants by incoming inflammatory cells and tissue cells may contribute to HO-1 activation [38], explaining higher $\mathrm{CO}$ levels in dual responders than in single responders.

HO-1 may be induced in various cells in the respiratory tract, such as epithelial cells and infiltrating inflammatory cells [39]. In a previous study, increased expression of HO-1 was shown in the alveolar macrophages of asthmatic patients when compared with normal subjects [19]. HO-1 activation may be the result of increased oxidative stress. The induction of HO-1 participates in the resolution of acute inflammation and plays a protective role in oxidant-induced cellular injuries [40].

No change was seen in $\mathrm{CO}$ during histamine-induced bronchoconstriction, indicating that bronchoconstriction itself does not influence $\mathrm{CO}$ levels and, therefore, the elevation of CO levels observed during allergen challenge is probably due to inflammation and oxidative stress, rather than changes in airway calibre.

There is evidence that NO induces HO-1 activity and $\mathrm{CO}$ production in vascular muscle cells [11]. This study has confirmed previously published data [25] showing elevated exhaled NO levels during the late asthmatic reaction in dual responders only, with a peak at $10 \mathrm{~h}$ after allergen challenge, which may be a reflection of iNOS induction. Indeed, a six-fold increase in iNOS expression has been shown at $4 \mathrm{~h}$ following allergen challenge in sensitized rats [7], whilst exhaled CO in the present study was highest at $6 \mathrm{~h}$. This may be due to a different time response of HO-1 and iNOS to their common activating inflammatory cytokines, IL-1 and TNF- $\alpha$. Furthermore, high levels of $\mathrm{CO}$ during the late reaction may inhibit iNOS activity [41], retarding the rise in NO. In single responders, exhaled CO but not NO [25] is elevated during the late reaction, which may indicate that $\mathrm{CO}$ is a more sensitive index of inflammation.

Measurement of exhaled carbon monoxide may be another means of detecting and monitoring cytokine- and oxidant-mediated inflammation and of assessing antiinflammatory treatments. In addition to its potential as a marker of inflammation, it is possible that the increase in exhaled carbon monoxide may be of pathophysiological significance. It will be necessary to intervene with specific inhibitors of haem oxygenase in the future in order to explore this possibility further.

\section{References}

1. Rahman I, Morrison D, Donaldson K, MacNee W. Systemic oxidative stress in asthma, COPD and smokers. Am $J$ Respir Crit Care Med 1996; 154: 1055-1060.

2. Barnes PJ. New aspects of asthma. J Intern Med 1992; 231: 453-461.

3. Wenzel SE, Larsen GL, Johnston K, Voelkel NF, Westcott JY. Elevated levels of leukotriene C4 in bronchoalveolar lavage fluid from atopic asthmatics after endobronchial allergen challenge. Am J Respir Crit Care Med 1990; 142: 112-119.

4. De Monchy JGR, Kauffman HP, Venge P, et al. Bronchoalveolar eosinophilia during allergen-induced late asthmatic reactions. Am Rev Respir Dis 1985; 131: 373-376.

5. Ohnishi T, Kita D, Weiler D, et al. IL-5 is the predominant eosinophil-active cytokine in the antigen-induced pulmonary late phase reaction. Am J Respir Crit Care Med 1993; 147: 901-907.

6. White KA, Marletta MA. Nitric oxide synthase is a cytochrome P-450 type hemoprotein. Biochemistry 1992; 31: 6627-6631.

7. Liu SF, Haddad EB, Adcock I, et al. Inducible nitric oxide synthase after sensitization and allergen challenge of Brown Norway rat lung. Br J Clin Pharmacol 1997; 121: 1241-1246.

8. Cantoni L, Rossi C, Rizzardini M, Gadina M, Ghezzi P. Interleukin 1 and tumor necrosis factor induce hepatic heme oxygenase feedback regulation by glucocorticoids. Biochem Biophys Res Commun 1991; 279: 891-894.

9. Lavrovksy Y, Drummond GS, Abraham NG. Downregulation of the human heme oxygenase gene by glucocorticoids and identification of $56 \mathrm{~b}$ regulatory elements. Biochem Biophys Res Commun 1996; 218: 759-765.

10. Kim YM, Bergonia HA, Muller C, Pitt BR, Watkins WD, Lancaster JR. Loss of degradation of enzyme-bound heme induced by cellular nitric oxide synthesis. J Biol Chem 1995; 270: 5710-5713.

11. Durante W, Kroll MH, Christodoulides N, Peyton KJ, Schafer AI. Nitric oxide induces heme oxygenase-1 gene expression and carbon monoxide production in vascular smooth muscle cells. Circ Res 1997; 80: 557-564.

12. Otterbein L, Sylvester SL, Choi AMK. Hemoglobin provides protection against lethal endotoxemia in rats: the role of heme oxygenase-1. Am J Respir Cell Mol Biol 1995; 13: 595-601.

13. Applegate LA, Luscher P, Tyrrel RM. Induction of heme oxygenase: a general response to oxidant stress in cultured mammalian cells. Cancer Res 1991; 51: 974-978.

14. Nath KA, Balla G, Vercellotti GM, et al. Induction of heme oxygenase is a rapid, protective response in rhab domyolysis in the rat. J Clin Invest 1992; 90: 267-270.

15. Augustine MK, Choi K, Alam J. Heme oxygenase-1: function, regulation, and implication of a novel stressinducible protein in oxidant-induced lung injury. $\mathrm{Am} \mathrm{J}$ Respir Cell Mol Biol 1996; 15: 9-19.

16. Morita T, Perella MA, Lee L, Kourembanas S. Smooth muscle cell-derived carbon monoxide is a regulator of vascular cGMP. Proc Natl Acad Sci USA 1995; 92: 14751479.

17. Verma A, Hirsch DJ, Glatt CE, Ronnett GV, Snyder SH. 
Carbon monoxide: a putative neural messenger. Science 1993; 259: 381-384.

18. Zayasu K, Sekizawa K, Okinaga S, Yamaya M, Sasaki H. Increased carbon monoxide in exhaled air of asthmatic patients. Am J Respir Crit Care Med 1997; 156: 1140-1143.

19. Horvath I, Donelly LE, Paredi P, Kharitonov SA, Barnes PJ. Elevated levels of exhaled carbon monoxide are associated with an increased expression of heme oxygenase-1 in airway macrophages in asthma: a new marker of chronic inflammation. Thorax 1998; 53: 668-672.

20. Barnes PJ. Nitric oxide and airways. Eur Respir J 1993; 6: 163-165.

21. Alving K, Weitzberg E, Lundberg JM. Increased amount of nitric oxide in exhaled air of asthmatics. Eur Respir $J$ 1993; 6: 1368-1370.

22. Kharitonov SA, Yates DH, Robbins RA, Logan-Sinclair R, Shinebourne EA, Barnes PJ. Increased nitric oxide in exhaled air of asthmatic patients. Lancet 1994; 343: 133135.

23. Kharitonov SA, Wells AU, O'Connor BJ, et al. Elevated levels of exhaled nitric oxide in bronchiectasis. Am J Respir Crit Care Med 1995; 151: 1889-1893.

24. Nathan C, Xie QW. Regulation of biosynthesis of nitric oxide. J Biol Chem 1994; 269: 13725-13728.

25. Kharitonov SA, O'Connor BJ, Evans DJ, Barnes PJ. Allergen-induced late asthmatic reactions are associated with elevation of exhaled nitric oxide. Am J Respir Crit Care Med 1995; 151: 1894-1899.

26. Deykin A, Halpern O, Masaro AF, Drazen JM, Israel E. Expired nitric oxide after bronchoprovocation and repeated spirometry in patients with asthma. Am J Respir Crit Care Med 1998; 157: 769-775.

27. Kharitonov SA, Paredi P, Barnes PJ. Levels of exhaled carbon monoxide are negatively flow dependent and positively related to duration of breathhold in normal and asthmatic subjects. Am J Respir Crit Care Med 1998; 157: A614.

28. Kharitonov SA, Barnes PJ. Nasal contribution to exhaled nitric oxide during exhalation against resistance or during breath holding. Thorax 1997; 52: 540-544.

29. Kharitonov SA, Chung KF, Evans DJ, O'Connor BJ, Barnes PJ. Increased exhaled nitric oxide in asthma is mainly derived from the lower respiratory tract. $\mathrm{Am} \mathrm{J}$ Respir Crit Care Med 1996; 153: 1773-1780.
30. Negishi M, Odani N, Koizumi T, Takahashi S, Ichikawa A. Involvement of protein kinase in delta 12-prostaglandin $\mathrm{J} 2$-induced expression of rat heme oxygenase-1 gene. FEBS Lett 1995; 372: 279-282.

31. Keyse SM, Tyrrel RM. Heme oxygenase is the major 32$\mathrm{kDa}$ stress protein induced in human skin fibroblasts by UVA radiation, hydrogen peroxide, and sodium arsenite. Proc Natl Acad Sci 1989; 86: 99-103.

32. Konno S, Gonokami Y, Kurokawa M, et al. Cytokine concentrations in sputum of asthmatic patients. Int Arch Allergy Immunol 1996; 109: 73-78.

33. Yokoyama A, Kohno N, Fujino S, et al. Circulating interleukin 6 levels in patients with bronchial asthma. Am J Respir Crit Care Med 1995; 151: 1354-1358.

34. Robbins RA, Springall DR, Warren JB, et al. Inducible nitric oxide synthase is increased in murine lung epithelial cells by cytokine stimulation. Biochem Biophys Res Commun 1994; 198: 835-843.

35. Robbins RA, Barnes PJ, Springall DR, et al. Expression of inducible nitric oxide in human lung epithelial cells. Biochem Biophys Res Commun 1994; 203: 209-218.

36. Ohkawara YK, Yamauchi K, Tanno Y, et al. Human lung mast cells and pulmonary macrophages produce tumor necrosis factor-alpha in sensitised lung tissue after $\mathrm{IgE}$ receptor triggering. Am J Respir Cell Mol Biol 1992; 7: 385-392.

37. Virchow JC Jr, Walker C, Hafner D, et al. T cell and cytokines in bronchoalveolar lavage fluid after segmental allergen provocation in atopic asthma. Am J Respir Crit Care Med 1995; 151: 960-968.

38. Keyse SM, Applegate LA, Tromvoukis Y, Tyrrel RM. Oxidant stress leads to transcriptional activation of the human heme oxygenase gene in cultured skin fibroblasts. Mol Cell Biol 1990; 10: 4967-4969.

39. Lee PJ, Alam J, Sylvester SL, Inamdar N, Otterbein L, Choi AMK. Regulation of heme oxygenase-1 expression in vivo and in vitro in hyperoxic lung injury. Am J Respir Cell Mol Biol 1996; 14: 556-568.

40. Willis D, Moore AR, Frederick R, Willoughby DA. Heme oxygenase: a novel target for the modulation of the inflammatory response. Nature Med 1996; 2: 87-90.

41. Klatt P, Schmidt K, Mayer B. Brain nitric oxide synthase is a haemoprotein. Biochem $J$ 1992; 288: 15-17. 